\title{
Synthesis and Evaluation of a New Series of Thiazolyl-pyrazoline Derivatives as Cholinesterase Inhibitors
}

\author{
Yeni Tiyazolil-Pirazolin Türevlerinin Sentezi ve Kolinesteraz İnhibitörleri \\ Olarak Değerlendirilmesi
}

\author{
(D) Halide Edip TEMEL1', (D) Mehlika Dilek ALTINTOP²*, (D) Ahmet ÖZDEMIR² \\ 'Anadolu University, Faculty of Pharmacy, Department of Biochemistry, Eskişehir, Turkey \\ ${ }^{2}$ Anadolu University, Faculty of Pharmacy, Department of Pharmaceutical Chemistry, Eskișehir, Turkey
}

\begin{abstract}
Objectives: In recent years, the design of anticholinesterase agents based on molecular hybridization of pharmacologically active scaffolds has attracted a great deal of interest in medicinal chemistry. For this purpose, we aimed to design and synthesize anticholinesterase agents based on the molecular hybridization of thiazole and pyrazoline scaffolds.

Materials and Methods: New thiazolyl-pyrazoline derivatives were synthesized via the ring closure reaction of 3-(2-furyl)-5-(1,3-benzodioxol-5-yl)1-thiocarbamoyl-4,5-dihydro-1H-pyrazole with 2-bromo-1-arylethanone derivatives. The compounds were investigated for their inhibitory effects on AChE and BuChE using a modification of Ellman's spectrophotometric method. As a part of this study, the compliance of the compounds to Lipinski's rule of five was evaluated. The physicochemical parameters (log P, TPSA, nrotb, molecular weight, number of hydrogen bond donors and acceptors, molecular volume) were calculated using Molinspiration software.

Results: 2-[5-(1,3-Benzodioxol-5-yl)-3-(2-furyl)-4,5-dihydro-1H-pyrazol-1-yl]-4-(naphthalen-2-yl)thiazole was found to be the most effective AChE inhibitor (38.5 $\pm 2.85 \%)$, whereas 2-[5-(1,3-benzodioxol-5-yl)-3-(2-furyl)-4,5-dihydro-1H-pyrazol-1-yl]-4-(4-fluorophenyl)thiazole was found as the most potent BuChE inhibitor $(43.02 \pm 2.71 \%)$ in this series. These compounds only violated one parameter of Lipinski's rule of five. On the basis of Lipinski's rule, they were expected to have reasonable oral bioavailability.

Conclusion: In the view of this study, the structural modification of the identified compounds is on-going for the generation of new cholinesterase inhibitors with enhanced efficacy.
\end{abstract}

Key words: Benzodioxole, cholinesterases, Lipinski's rule of five, pyrazoline, thiazole

ÖZ

Amaç: Son yıllarda, medisinal kimyada farmakolojik olarak aktif halkaların moleküler hibridizasyonuna dayalı antikolinesteraz ajanların tasarımı ilgi çekmektedir. Bu amaçla, burada tiyazol ve pirazolin halkalarının moleküler hibridizasyonuna dayalı antikolinesteraz ajanlar tasarlamayı ve sentezlemeyi hedefledik.

Gereç ve Yöntemler: 3-(2-Furil)-5-(1,3-benzodioksol-5-il)-1-tiyokarbamoil-4,5-dihidro-1H-pirazolün 2-bromo-1-ariletanon türevleri ile halka kapanma reaksiyonuyla yeni tiyazolil-pirazolin türevleri sentezlendi. Bileşikler, Ellman'ın spektrofotometrik yönteminin bir modifikasyonu kullanılarak AChE ve BuChE üzerindeki inhibe edici etkileri için araştırıldı. Bu çalışmanın bir parçası olarak, bileşiklerin Lipinski'nin beş kuralına uyumluluğu değerlendirildi. Fizikokimyasal parametreler (log P, TPSA, nrotb, molekül ağırlığı, hidrojen bağı donörlerinin ve alıcılarının sayıSı, molekül hacmi) Molinspiration yazılımı kullanılarak hesaplandı.

Bulgular: Bu seride, 2-[5-(1,3-benzodioksol-5-il)-3-(2-furil)-4,5-dihidro-1H-pirazol-1-il]-4-(4-florofenil)tiyazol en güçlü BuChE inhibitörü (\%43.02 \pm 2.71$)$ olarak bulunurken, 2-[5-(1,3-benzodioksol-5-il)-3-(2-furil)-4,5-dihidro-1H-pirazol-1-il]-4-(naftalen-2-il)tiyazolün en etkili AChE inhibitörü (\%38.5 2.85) olduğu bulundu. Bu bileşikler, Lipinski'nin beş kuralının sadece bir parametresini ihlal ettiler. Lipinski'nin kuralına dayanarak, makul oral biyoyararlanıma sahip olmaları beklenmektedir.

Sonuç: Bu çalışmanın ışığında, etkinliği artırıımış yeni kolinesteraz inhibitörlerinin üretilmesi için tanımlanmış bileșiklerin yapısal modifikasyonu devam etmektedir.

Anahtar kelimeler: Benzodioksol, kolinesterazlar, Lipinski'nin 5 kuralı, pirazolin, tiyazol

*Correspondence: E-mail: mdaltintop@anadolu.edu.tr, Phone: +90 5352586735 ORCID-ID: orcid.org/0000-0002-8159-663X

Received: 08.09.2017, Accepted: 30.11.2017

Turk J Pharm Sci, Published by Galenos Publishing House. 


\section{INTRODUCTION}

Alzheimer's disease (AD), a progressive multifarious neurodegenerative disorder, is the leading cause of dementia in older people worldwide. The incidence of $A D$ is predicted to increase dramatically in the future, as the average age of the population increases. Although extensive efforts have been devoted to the discovery of anti-AD drugs for almost a century, donepezil, galantamine, rivastigmine (cholinesterase inhibitors) and memantine ( $\mathrm{N}$-methyl-D-aspartate receptor antagonist) are the only drugs currently used for the management of $A D$. These agents only provide symptomatic relief but do not halt the progression of the disease..$^{1-5}$

The development of new potent anti-AD drugs is a difficult and time-consuming process, and many molecules reaching clinical trials simply fail. Most phase 2 clinical trials ending with a positive outcome do not succeed in phase 3 , often due to serious adverse effects or lack of therapeutic efficacy. ${ }^{6,7}$

Acetylcholinesterase (AChE) is a highly viable target for the design and development of potent anti-AD agents due to its role in the pathogenesis of $A D .^{1-8}$ On the other hand, in progressed $A D$, the level of AChE in the brain declines to $55-67 \%$ of normal values, whereas the level of butyrylcholinesterase (BuChE) increases to $120 \%$ of normal levels, indicating that BuChE plays a pivotal role for acetylcholine (ACh) hydrolysis in the late stage of AD. As a result, selective inhibition of BuChE has emerged as a promising therapeutic approach to elevate ACh level in progressed AD.9.10

Thiazole has been recognized as a promising scaffold for the design and development for central nervous system (CNS) active agents. There are thiazole-based CNS drugs currently used as therapeutic agents for the treatment of various CNS disorders and a number of thiazole derivatives are in clinical trials." Diverse modifications of the thiazole ring at various positions have led to a variety of thiazole-based CNS agents as AChE and BuChE inhibitors, secretase inhibitors, monoamine oxidase (MAO) inhibitors, neuronal nitric oxide synthase inhibitors, ACh receptor ligands, adenosine receptor ligands, dopamine receptor ligands, serotonin receptor ligands, glutamate receptor ligands, $\gamma$-aminobutyric acid receptor ligands, opioid receptor ligands, neuroprotective and anticonvulsant agents. ${ }^{11-14}$ Acotiamide has been reported to be a promising thiazole-based agent for the treatment of functional dyspepsia in clinical trials. Acotiamide enhances $A C h$ release in the enteric nervous system through AChE inhibition and M1/M2 muscarinic receptor antagonism. ${ }^{15}$

Pyrazoline has also attracted a great deal of interest as an indispensable scaffold due to its diverse therapeutic applications extending from CNS applications to antimicrobial therapy. ${ }^{16,17}$ Diversely substituted pyrazolines embedded with a variety of functional groups have been reported to inhibit MAOs and cholinesterases, molecular targets important for the treatment of neurodegenerative disorders such as Parkinson's disease and AD. ${ }^{16-23}$

Prompted by the aforementioned findings and in the continuation of our ongoing research on thiazoles ${ }^{24}$ and pyrazolines ${ }^{25}$ as cholinesterase inhibitors, we designed a new series of thiazolyl- pyrazoline derivatives based on the molecular hybridization of thiazole and pyrazoline scaffolds. ${ }^{26} A$ facile and versatile synthetic route was used to prepare the title compounds and their inhibitory effects on AChE and BuChE were investigated. A computational study for the prediction of Absorption, Distribution, Metabolism and Excretion (ADME) properties of all compounds was also performed.

\section{MATERIALS AND METHODS}

\section{Chemistry}

All reagents were purchased from commercial suppliers and were used without further purification. Melting points (MP) were determined on an Electrothermal 9100 MP apparatus (Weiss-Gallenkamp, Loughborough, UK). ${ }^{1} \mathrm{H}-\mathrm{NMR}$ spectra were recorded on a Bruker spectrometer (Bruker, Billerica, MA, USA). Mass spectra were recorded on an Agilent LC-MSD-TrapSL Mass spectrometer (Agilent, Minnesota, USA). Elemental analyses $(\mathrm{C}, \mathrm{H}, \mathrm{N}$ ) were performed on a Perkin Elmer EAL 240 elemental analyzer (Perkin-Elmer, Norwalk, CT, USA) and the results were within $\pm 0.4 \%$ of the theoretical values. Thin layer chromatography (TLC) was performed on TLC Silica gel $60 \mathrm{~F}_{254}$ aluminium sheets (Merck, Darmstadt, Germany) to check the purity of the compounds.

General procedure for the synthesis of the compounds 1-(2-furanyl)-3-(1,3-benzodioxol-5-yl)-2-propen-1-one (1)

A mixture of 2-acetylfuran (0.06 mol), 1,3-benzodioxole-5carboxaldehyde $(0.06 \mathrm{~mol})$ and $40 \%(\mathrm{w} / \mathrm{v})$ sodium hydroxide $(10 \mathrm{~mL})$ in ethanol $(30 \mathrm{~mL})$ was stirred at room temperature for about $24 \mathrm{~h}$. The resulting solid was washed, dried, and crystallized from ethanol. 27,28

3-(2-furanyl)-5-(1,3-benzodioxol-5-yl)-1-thiocarbamoyl-4,5dihydro-1H-pyrazole (2)

A mixture of compound 1 ( $0.03 \mathrm{~mol})$, thiosemicarbazide $(0.036$ $\mathrm{mol})$ and sodium hydroxide $(0.075 \mathrm{~mol})$ was refluxed in ethanol $(30 \mathrm{~mL}$ ) for $12 \mathrm{~h}$. The product was poured into crushed ice. The precipitate was filtered and crystallized from ethanol. ${ }^{29}$

2-[5-(1,3-benzodioxol-5-yl)-3-(furan-2-yl)-4,5-dihydro-1Hpyrazol-1-yl]-4-(aryl)thiazole (3a-g)

A mixture of compound 2 (0.01 mol), 2-bromo-1-arylethanone $(0.01 \mathrm{~mol})$ in ethanol $(20 \mathrm{~mL})$ was refluxed for $10 \mathrm{~h}$. After cooling, the precipitate was collected by suction filtration. The product was crystallized from ethanol. ${ }^{29}$

2-[5-(1,3-benzodioxol-5-yl)-3-(furan-2-yl)-4,5-dihydro-1Hpyrazol-1-yl]-4-(4-(methylsulfonyl)phenyl)thiazole (3a)

Yield: $76 \%$; MP: $178-179^{\circ} \mathrm{C}$.

${ }^{1} \mathrm{H}-\mathrm{NMR}\left(400 \mathrm{MHz}, \mathrm{DMSO}-d_{6}\right) \delta$ (ppm): 2.99-3.00 (1H, m), 3.22 $(3 \mathrm{H}, \mathrm{s}), 3.92(1 \mathrm{H}, \mathrm{dd}, \mathrm{J}=17.36,11.16 \mathrm{~Hz}), 5.57(1 \mathrm{H}, \mathrm{dd}, \mathrm{J}=11.52,5.96$ $\mathrm{Hz}), 5.93(2 \mathrm{H}, \mathrm{s}), 6.65(1 \mathrm{H}, \mathrm{s}), 6.87-6.95(4 \mathrm{H}, \mathrm{m}), 7.59(1 \mathrm{H}, \mathrm{s})$, $7.86(3 \mathrm{H}, \mathrm{d}, \mathrm{J}=8.72 \mathrm{~Hz}), 7.94(2 \mathrm{H}, \mathrm{d}, J=7.44 \mathrm{~Hz})$.

Elemental analysis calculated (Anal. calcd) for $\mathrm{C}_{24} \mathrm{H}_{19} \mathrm{~N}_{3} \mathrm{O}_{5} \mathrm{~S}_{2}(\%)$ : C, 58.40; H, 3.88; N, 8.51. Found (\%): C, 58.45; H, 3.89; N, 8.58. MS (ESI) $m / z: 494[\mathrm{M}+\mathrm{H}]^{+}$. 
2-[5-(1,3-benzodioxol-5-yl)-3-(furan-2-yl)-4,5-dihydro-1Hpyrazol-1-yl]-4-(4-(trifluoromethyl)phenyl)thiazole (3b)

Yield: $80 \%$; MP: $77-78^{\circ} \mathrm{C}$.

${ }^{1} \mathrm{H}-\mathrm{NMR}\left(400 \mathrm{MHz}, \mathrm{DMSO}-d_{6}\right) \delta(\mathrm{ppm}): 3.12-3.13(1 \mathrm{H}, \mathrm{m}), 3.90$ $(1 \mathrm{H}, \mathrm{dd}, \mathrm{J}=18.32,12.20 \mathrm{~Hz}), 5.57(1 \mathrm{H}, \mathrm{dd}, \mathrm{J}=11.48,5.96 \mathrm{~Hz}), 5.94$ $(2 \mathrm{H}, \mathrm{s}), 6.65(1 \mathrm{H}, \mathrm{s}), 6.86-6.96(4 \mathrm{H}, \mathrm{m}), 7.55(1 \mathrm{H}, \mathrm{s}), 7.69(2 \mathrm{H}, \mathrm{d}$, $\mathrm{J}=8.12 \mathrm{~Hz}), 7.88-7.92(3 \mathrm{H}, \mathrm{m})$.

Anal. calcd for $\mathrm{C}_{24} \mathrm{H}_{16} \mathrm{~F}_{3} \mathrm{~N}_{3} \mathrm{O}_{3} \mathrm{~S}$ (\%): C, 59.62; $\mathrm{H}, 3.34 ; \mathrm{N}, 8.69$. Found (\%): C, 59.57; H, 3.39; N, 8.78.

MS (ESI) $\mathrm{m} / \mathrm{z}: 484[\mathrm{M}+\mathrm{H}]^{+}$.

2-[5-(1,3-benzodioxol-5-yl)-3-(furan-2-yl)-4,5-dihydro-1Hpyrazol-1-yl]-4-(4-fluorophenyl)thiazole (3c)

Yield: $81 \%$; MP: $89-90^{\circ} \mathrm{C}$.

${ }^{1} \mathrm{H}-\mathrm{NMR}\left(400 \mathrm{MHz}, \mathrm{DMSO}-d_{6}\right) \delta$ (ppm): 3.10-3.11 $(1 \mathrm{H}, \mathrm{m}), 3.89$ $(1 \mathrm{H}, \mathrm{dd}, J=17.76,11.80 \mathrm{~Hz}), 5.55(1 \mathrm{H}, \mathrm{dd}, J=11.52,5.92 \mathrm{~Hz}), 5.94$ $(2 \mathrm{H}, \mathrm{s}), 6.64-6.65(1 \mathrm{H}, \mathrm{m}), 6.85-6.94(4 \mathrm{H}, \mathrm{m}), 7.14-7.28(3 \mathrm{H}, \mathrm{m})$, 7.71-7.75 (2H, m), 7.86-7.87 (1H, m).

Anal. calcd for $\mathrm{C}_{23} \mathrm{H}_{16} \mathrm{FN}_{3} \mathrm{O}_{3} \mathrm{~S}(\%)$ : C, 63.73; $\mathrm{H}, 3.72 ; \mathrm{N}, 9.69$. Found (\%): C, 63.69; H, 3.77; N, 9.63.

MS (ESI) $\mathrm{m} / \mathrm{z}: 434[\mathrm{M}+\mathrm{H}]^{+}$.

2-[5-(1,3-benzodioxol-5-yl)-3-(furan-2-yl)-4,5-dihydro-1Hpyrazol-1-yl]-4-(2,6-difluorophenyl)thiazole (3d)

Yield: $78 \%$; MP: $137-138^{\circ} \mathrm{C}$.

${ }^{1} \mathrm{H}-\mathrm{NMR}$ (400 MHz, DMSO-d $)$ $\delta$ (ppm): 3.13-3.14 (1H, m), 3.93 $(1 \mathrm{H}, \mathrm{dd}, J=17.73,11.82 \mathrm{~Hz}), 5.58(1 \mathrm{H}, \mathrm{dd}, \mathrm{J}=11.70,6.30 \mathrm{~Hz}), 5.98$ $(2 \mathrm{H}, \mathrm{s}), 6.67-6.69(1 \mathrm{H}, \mathrm{m}), 6.88-6.98(4 \mathrm{H}, \mathrm{m}), 7.10-7.21(2 \mathrm{H}, \mathrm{m})$, 7.26-7.34 (1H, m), 7.83-7.90 (2H, m).

Anal. calcd for $\mathrm{C}_{23} \mathrm{H}_{15} \mathrm{~F}_{2} \mathrm{~N}_{3} \mathrm{O}_{3} \mathrm{~S}(\%): \mathrm{C}, 61.19 ; \mathrm{H}, 3.35 ; \mathrm{N}, 9.31$. Found (\%): C, 61.13; H, 3.42; N, 9.33.

MS (ESI) $\mathrm{m} / \mathrm{z}: 452[\mathrm{M}+\mathrm{H}]^{+}$.

2-[5-(1,3-benzodioxol-5-yl)-3-(furan-2-yl)-4,5-dihydro-1Hpyrazol-1-yl]-4-(2,5-dimethoxyphenyl)thiazole (3e)

Yield: $77 \%$; MP: $113-114^{\circ} \mathrm{C}$.

${ }^{1} \mathrm{H}-\mathrm{NMR}\left(400 \mathrm{MHz}, \mathrm{DMSO}-d_{6}\right) \delta$ (ppm): 3.03-3.04 $(1 \mathrm{H}, \mathrm{m}), 3.68$ $(3 \mathrm{H}, \mathrm{s}), 3.76(3 \mathrm{H}, \mathrm{m}), 3.88(1 \mathrm{H}, \mathrm{dd}, \mathrm{J}=17.84,12.24 \mathrm{~Hz}), 5.50(1 \mathrm{H}$, dd, J=11.52, $7.08 \mathrm{~Hz}), 5.94(2 \mathrm{H}, \mathrm{s}), 6.64-6.65(1 \mathrm{H}, \mathrm{m}), 6.75-6.94$ $(5 \mathrm{H}, \mathrm{m}), 7.07-7.19(2 \mathrm{H}, \mathrm{m}), 7.38-7.41(1 \mathrm{H}, \mathrm{m}), 7.87(1 \mathrm{H}, \mathrm{s})$.

Anal. calcd for $\mathrm{C}_{25} \mathrm{H}_{21} \mathrm{~N}_{3} \mathrm{O}_{5} \mathrm{~S}$ (\%): C, 63.15; $\mathrm{H}, 4.45 ; \mathrm{N}, 8.84$. Found (\%): C, 63.11; H, 4.42; N, 8.85.

MS (ESI) $\mathrm{m} / \mathrm{z}: 476[\mathrm{M}+\mathrm{H}]^{+}$.

2-[5-(1,3-benzodioxol-5-yl)-3-(furan-2-yl)-4,5-dihydro-1Hpyrazol-1-yl]-4-[4-(morpholin-4-yl)phenyl]thiazole (3f)

Yield: $78 \%$; MP: $210-211^{\circ} \mathrm{C}$.

${ }^{1} \mathrm{H}-\mathrm{NMR}\left(400 \mathrm{MHz}, \mathrm{DMSO}-d_{6}\right) \delta(\mathrm{ppm}): 3.01-3.02(1 \mathrm{H}, \mathrm{m}), 3.08$ (4H, bs), $3.69(4 \mathrm{H}, \mathrm{s}), 3.87(1 \mathrm{H}, \mathrm{dd}, \mathrm{J}=17.60,12.72 \mathrm{~Hz}), 5.54(1 \mathrm{H}$, dd, J=12.44, $5.20 \mathrm{~Hz}), 5.93(2 \mathrm{H}, \mathrm{s}), 6.59-6.64(3 \mathrm{H}, \mathrm{m}), 6.80-6.94$ $(6 \mathrm{H}, \mathrm{m}), 7.55(1 \mathrm{H}, \mathrm{s}), 7.86(1 \mathrm{H}, \mathrm{s})$.

Anal. calcd for $\mathrm{C}_{27} \mathrm{H}_{24} \mathrm{~N}_{4} \mathrm{O}_{4} \mathrm{~S}(\%)$ : C, 64.78; H, 4.83; N, 11.19. Found (\%): C, 64.72; H, 4.88; N, 11.16.

MS (ESI) $\mathrm{m} / \mathrm{z}: 501[\mathrm{M}+\mathrm{H}]^{+}$.
2-[5-(1,3-benzodioxol-5-yl)-3-(furan-2-yl)-4,5-dihydro-1Hpyrazol-1-yl]-4-(naphthalen-2-yl)thiazole (3g)

Yield: 83\%; MP: $153-154^{\circ} \mathrm{C}$.

${ }^{1} \mathrm{H}-\mathrm{NMR}$ (400 MHz, DMSO-d $) \delta$ (ppm): $3.09(1 \mathrm{H}, \mathrm{dd}, J=17.76$, $2.72 \mathrm{~Hz}), 3.78(1 \mathrm{H}, \mathrm{dd}, \mathrm{J}=17.96,11.48 \mathrm{~Hz}), 5.80(1 \mathrm{H}, \mathrm{dd}, \mathrm{J}=11.12$, $2.68 \mathrm{~Hz}), 5.94(2 \mathrm{H}, \mathrm{s}), 6.59-6.87(6 \mathrm{H}, \mathrm{m}), 7.06(1 \mathrm{H}, \mathrm{s}), 7.19(1 \mathrm{H}$, s), $7.69(1 \mathrm{H}, \mathrm{s}), 7.81(1 \mathrm{H}, \mathrm{s}), 7.88(1 \mathrm{H}, \mathrm{s}), 7.95(2 \mathrm{H}, \mathrm{d}, \mathrm{J}=8.80 \mathrm{~Hz})$, 8.16-8.19 $(1 \mathrm{H}, \mathrm{m})$.

Anal. calcd for $\mathrm{C}_{27} \mathrm{H}_{19} \mathrm{~N}_{3} \mathrm{O}_{3} \mathrm{~S}$ (\%): C, 69.66; $\mathrm{H}, 4.11 ; \mathrm{N}, 9.03$. Found (\%): C, 69.75; H, 4.29; N, 9.06.

MS (ESI) $\mathrm{m} / \mathrm{z}: 466[\mathrm{M}+\mathrm{H}]^{+}$.

\section{Determination of AChE and BuChE inhibitory activity}

The inhibitory effects of compounds $3 \mathrm{a}-\mathrm{g}$ on $\mathrm{AChE}$ and BuChE were determined using Ellman's method ${ }^{30}$ with minor modifications (electric eel AChE enzyme was used instead of bovine AChE enzyme and buffer was added as $2.4 \mathrm{~mL}$ instead of $3 \mathrm{~mL}){ }^{31}$ The compounds were dissolved in DMSO and tested at the final concentration range $5-80 \mu \mathrm{g} / \mathrm{mL}$. Twenty microliters of enzyme (AChE or BuChE, $1 \mathrm{U} / \mathrm{mL}$ ) and $10 \mu \mathrm{L}$ sample were added to $2.4 \mathrm{~mL}$ buffer, the mixture was incubated at $37^{\circ} \mathrm{C}$ for 15

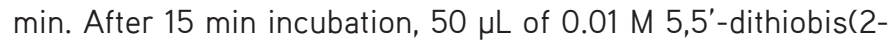
nitrobenzoic acid) (DTNB) and $20 \mu \mathrm{L}$ of $75 \mathrm{mM}$ acetylthiocholine iodide or $25 \mathrm{mM}$ butyrylthiocholine iodide were added, and the final mixture was incubated at room temperature for 30 min. A blank was prepared using $10 \mu \mathrm{L}$ of DMSO instead of the test sample, with all other procedures similar to those used in the case of the sample mixture. Absorbances were measured at $412 \mathrm{~nm}$ and $37^{\circ} \mathrm{C}$ using polystyrene cuvettes with a spectrophotometer (UV-1700, Shimadzu). The experiment was performed in triplicate. Galantamine was used as a positive control. Data are expressed as mean \pm standard deviation. The inhibition (percent) of AChE or BuChE was calculated using the following equation:

$I(\%)=100-\left(O D_{\text {sample }} / O D_{\text {control }}\right) \times 100$

In silico prediction of ADME parameters

The physicochemical parameters [logarithm of octanol/ water partition coefficient (log $P$ ), topological polar surface area (TPSA), number of rotatable bonds (nrotb), molecular weight, number of hydrogen bond donors and acceptors, molecular volume] of compounds $3 \mathrm{a}-\mathrm{g}$ were calculated using Molinspiration software. ${ }^{32-35}$

There was no need for ethics committee approval because our work only included in vitro and in silico studies.

\section{RESULTS AND DISCUSSION}

The synthesis of thiazole derivatives $(3 \mathrm{a}-\mathrm{g})$ followed the general pathway outlined in Scheme 1. The base-catalyzed ClaisenSchmidt condensation of 2-acetylfuran with 1,3-benzodioxole5-carboxaldehyde gave 1-(2-furanyl)-3-(1,3-benzodioxol5-yl)-2-propen-1-one (1), which underwent a subsequent cyclization reaction with thiosemicarbazide in the presence of sodium hydroxide affording 3-(2-furanyl)-5-(1,3-benzodioxol- 
5-yl)-1-thiocarbamoyl-4,5-dihydro-1H-pyrazole (2). Finally, new thiazolyl-pyrazoline derivatives $(3 \mathrm{a}-\mathrm{g})$ were synthesized via the ring closure reactions of compound 2 with 2-bromo-1arylethanone derivatives.
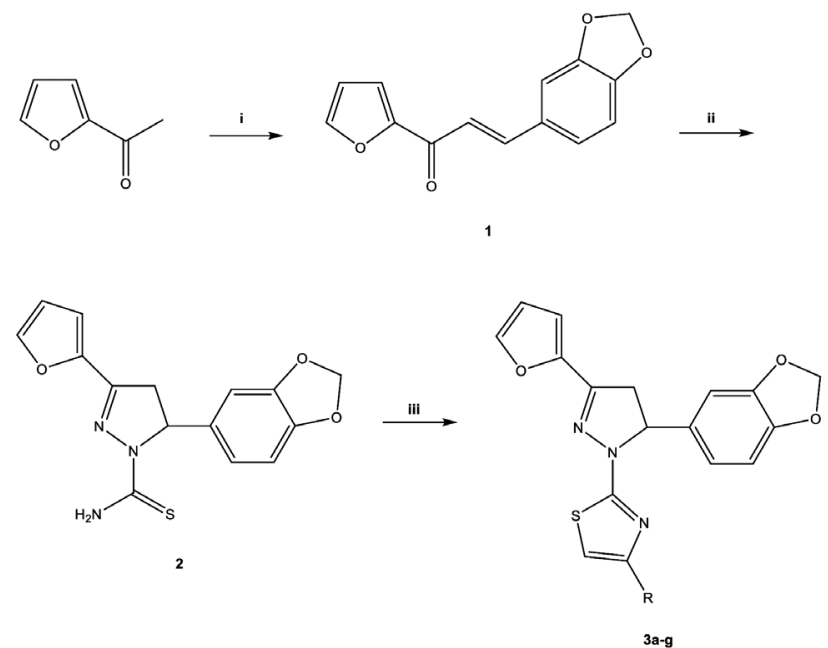

$R=$<smiles>Cc1ccc(S(C)(=O)=O)cc1</smiles><smiles>Cc1ccc(C)cc1</smiles><smiles>Cc1ccc(F)cc1</smiles><smiles>Cc1c(F)cccc1F</smiles>

sb

3c<smiles>COc1ccc(OC)c(C)c1</smiles><smiles>Cc1ccc(N2CCOCC2)cc1</smiles><smiles>Cc1ccc2ccccc2c1</smiles>

$$
3 \mathbf{f}
$$

Scheme 1. The synthetic route for the preparation of compounds 3a-g. Reagents and conditions: (i) 1,3-benzodioxole-5-carboxaldehyde, 40\% (w/v) $\mathrm{NaOH}$, ethanol, rt, $24 \mathrm{~h}$; (ii) thiosemicarbazide, $\mathrm{NaOH}$, ethanol, reflux, $12 \mathrm{~h}$; (iii) 2-bromo-1-arylethanone, ethanol, reflux, $10 \mathrm{~h}$

The inhibitory effects of compounds $3 a-g$ on AChE and BuChE were determined using a modification of Ellman's spectrophotometric method (Table 1). Galantamine was used as a positive control. According to the results, compounds $3 \mathrm{a}-\mathrm{g}$ showed less ChE inhibitory activity than galantamine.

Compounds $3 a, 3 b, 3 e, 3 f$ and $3 g$ showed less than $50 \%$ AChE inhibition at $80 \mu \mathrm{g} / \mathrm{mL}$, whereas compounds $3 \mathrm{c}$ and $3 \mathrm{~d}$ showed no inhibitory activity against AChE. Compound $3 \mathrm{~g}$ was identified as the most potent AChE inhibitor (38.5 $\pm 2.85 \%)$ in this series. This outcome indicated that naphthalene ring enhanced the inhibitory activity against AChE. The increased activity can be attributed to its high lipophilicity due to the presence of naphthalene moiety.

Compounds $3 \mathrm{a}, 3 \mathrm{f}$ and $3 \mathrm{~g}$ showed no inhibitory activity against BuChE, whereas the other compounds showed BuChE inhibitory activity ranging from 43.02 to $21.44 \%$. The most selective BuChE inhibitor was found as compound $3 c(43.02 \pm 2.71 \%)$ followed by compound $3 \mathrm{~d}(38.52 \pm 3.33 \%)$. This outcome pointed out the importance of fluoro substituent for BuChE inhibitory activity.

Table 1. The inhibitory effects of compounds $3 a-g$ on AChE and BuChE

\begin{tabular}{lll}
\hline \multirow{2}{*}{ Compound } & \multicolumn{2}{l}{ Inhibition\% $(80 \mu \mathrm{g} / \mathrm{mL})$} \\
\cline { 2 - 3 } & AChE & BuChE \\
\hline 3a & $8.60 \pm 1.29$ & --- \\
\hline 3b & $29.57 \pm 2.31$ & $24.24 \pm 2.62$ \\
\hline 3c & --- & $43.02 \pm 2.71$ \\
\hline 3d & --- & $38.52 \pm 3.33$ \\
\hline 3e & $25.62 \pm 3.23$ & $21.44 \pm 2.85$ \\
\hline 3f & $19.79 \pm 0.41$ & --- \\
\hline 3g & $38.5 \pm 2.85$ & --- \\
\hline Galantamine & $(97.17 \pm 0.48)^{\mathrm{a}}$ & $(80.98 \pm 0.22)^{\mathrm{a}}$
\end{tabular}

---: No inhibition. alnhibition\% at $16 \mu \mathrm{g} / \mathrm{mL}$, AChE: Acetylcholinesterase, BuChE: Butyrylcholinesterase

Table 2. Pharmacokinetic parameters important for bioavailability of compounds 3a-g

\begin{tabular}{|c|c|c|c|c|c|c|c|c|}
\hline \multirow{2}{*}{ Compound } & \multicolumn{8}{|c|}{ Molecular properties ${ }^{a}$} \\
\hline & MW & $\log P$ & TPSA & nrotb & HBA & HBD & Volume & Violations \\
\hline $3 a$ & 493.57 & 4.00 & 94.24 & 5 & 8 & 0 & 397.15 & 0 \\
\hline $3 b$ & 483.47 & 6.03 & 60.10 & 5 & 6 & 0 & 380.45 & 1 \\
\hline $3 c$ & 433.46 & 5.30 & 60.10 & 4 & 6 & 0 & 354.08 & 1 \\
\hline $3 d$ & 451.45 & 5.37 & 60.10 & 4 & 6 & 0 & 359.02 & 1 \\
\hline $3 e$ & 475.53 & 5.17 & 78.57 & 6 & 8 & 0 & 400.25 & 1 \\
\hline $3 f$ & 500.58 & 5.08 & 72.57 & 5 & 8 & 0 & 427.29 & 2 \\
\hline $3 g$ & 465.53 & 6.32 & 60.10 & 4 & 6 & 0 & 393.15 & 1 \\
\hline
\end{tabular}

a Molecular properties were calculated using Molinspiration software.

MW: Molecular weight, log P: The logarithm of octanol/water partition coefficient, TPSA: Topological polar surface area, nrotb: Number of rotatable bonds, HBA: Number of hydrogen bond acceptors, HBD: Number of hydrogen bond donors 
As a part of this study, Molinspiration software was used to determine their physicochemical parameters (log P, TPSA, nrotb, molecular weight, number of hydrogen bond donors and acceptors, molecular volume) for the evaluation of the compliance of the compounds to Lipinski's rule of five. ${ }^{32}$ This rule states that most 'drug-like' molecules have log $P \leq 5$, molecular weight $\leq 500$, number of hydrogen bond acceptors $\leq 10$, and number of hydrogen bond donors $\leq 5$. Compounds violating more than one of these rules may have bioavailability problems. ${ }^{32-35}$ According to in silico studies, compounds $3 \mathrm{~b}, 3 \mathrm{c}, 3 \mathrm{~d}, 3 \mathrm{e}$, and $\mathbf{3 g}$ only violated one parameter of Lipinski's rule of five, whereas compound 3 a did not violate Lipinski's rule (Table 2). On the basis of Lipinski's rule of five, they were expected to have good oral bioavailability. On the other hand, compound $3 \mathrm{f}$ violated two parameters of Lipinski's rule of five, and therefore it can be concluded that compound $\mathbf{3 f}$ may have bioavailability problems.

\section{CONCLUSIONS}

In the current work, new thiazolyl-pyrazoline derivatives were synthesized and investigated for their in vitro inhibitory effects on AChE and BuChE. Moreover, the compliance of the compounds to Lipinski's rule of five was evaluated. Naphthalene-substituted compound $3 \mathrm{~g}$ was the most potent AChE inhibitor (38.5 $\pm 2.85 \%$ ), whereas fluoro-substituted compound $3 c$ was the most effective BuChE inhibitor $(43.02 \pm 2.71 \%)$ in this series. In the view of this work, the structural modification of the identified compounds is on-going for the generation of new anticholinesterase agents with enhanced efficacy and selectivity.

Conflict of Interest: No conflict of interest was declared by the authors.

\section{REFERENCES}

1. Kumar A, Singh A, Ekavali. A review on Alzheimer's disease pathophysiology and its management: an update. Pharmacol Rep. 2015;67:195-203.

2. Guzior N, Wieckowska A, Panek D, Malawska B. Recent Development of multifunctional agents as potential drug candidates for the treatment of Alzheimer's disease. Curr Med Chem. 2015;22:373-404.

3. Silva T, Reis J, Teixeira J, Borges F. Alzheimer's disease, enzyme targets and drug discovery struggles: From natural products to drug prototypes. Ageing Res Rev. 2014;15:116-145.

4. Anand R, Gill KD, Mahdi AA. Therapeutics of Alzheimer's disease: Past, present and future. Neuropharmacology. 2014;76:27-50.

5. Tayeb HO, Yang HD, Price BH, Tarazi Fl. Pharmacotherapies for Alzheimer's disease: Beyond cholinesterase inhibitors. Pharmacol Ther. 2012;134:8-25.

6. Godyn J, Jonczyk J, Panek D, Malawska B. Therapeutic strategies for Alzheimer's disease in clinical trials. Pharmacol Rep. 2016;68:127-138.

7. Sikazwe D, Yendapally R, Ramsinghani S, Khan M. Alzheimer's drug discovery maze: A snap view of the past decade's diverse pharmacological targets for the disorder. Mini-Rev Med Chem. 2017;17:305-318.

8. Wang $\mathrm{Y}$, Wang $\mathrm{H}$, Chen $\mathrm{HZ}$. AChE inhibition-based multi-target-directed ligands, a novel pharmacological approach for the symptomatic and disease-modifying therapy of Alzheimer's disease. Curr Neuropharmacol.
2016;14:364-375.

9. Li $Q$, Yang $H$, Chen $Y$, Sun $H$. Recent progress in the identification of selective butyrylcholinesterase inhibitors for Alzheimer's disease. Eur $\mathrm{J}$ Med Chem. 2017;132:294-309.

10. Greig NH, Utsuki T, Yu Q, Zhu X, Holloway HW, Perry T, Lee B, Ingram DK, Lahiri DK. A new therapeutic target in Alzheimer's disease treatment: attention to butyrylcholinesterase. Curr Med Res Opin. 2001;17:159-165.

11. Mishra CB, Kumari S, Tiwari M. Thiazole: A promising heterocycle for the development of potent CNS active agents. Eur J Med Chem. 2015;92:134.

12. Ayati A, Emami S, Asadipour A, Shafiee A, Foroumadi A. Recent applications of 1,3-thiazole core structure in the identification of new lead compounds and drug discovery. Eur J Med Chem. 2015;97:699-718.

13. Sun ZQ, Tu LX, Zhuo FJ, Liu SX. Design and discovery of novel thiazole acetamide derivatives as anticholinesterase agent for possible role in the management of Alzheimer's. Bioorg Med Chem Lett. 2016;26:747750 .

14. D'Ascenzio M, Chimenti P, Gidaro MC, De Monte C, De Vita D, Granese A, Scipione L, Di Santo R, Costa G, Alcaro S, Yáñez M, Carradori S. (Thiazol2-yl) hydrazone derivatives from acetylpyridines as dual inhibitors of MAO and AChE: synthesis, biological evaluation and molecular modeling studies, J Enzyme Inhib Med Chem. 2015;30:908-919.

15. Zala AV, Walker MM, Talley NJ. Emerging drugs for functional dyspepsia. Expert Opin Emerg Drugs. 2015;20:221-233.

16. Shaaban MR, Mayhoub AS, Farag AM. Recent advances in the therapeutic applications of pyrazolines. Expert Opin Ther Pat. 2012;22:253-291.

17. Alex JM, Kumar R. 4,5-Dihydro-1H-pyrazole: an indispensable scaffold. J Enzyme Inhib Med Chem. 2014;29:427-442.

18. Kumar S, Bawa S, Drabu S, Kumar R, Gupta H. Biological activities of pyrazoline derivatives $-A$ recent development. Recent Pat Anti-Infect Drug Discov. 2009;4:154-163.

19. Secci D, Bolasco A, Chimenti P, Carradori S. The state of the art of pyrazole derivatives as monoamine oxidase Inhibitors and antidepressant/ anticonvulsant agents. Curr Med Chem. 2011;18:5114-5144.

20. Ucar G, Gokhan N, Yesilada A, Bilgin AA. 1-N-Substituted thiocarbamoyl3-phenyl-5-thienyl-2-pyrazolines: A novel cholinesterase and selective monoamine oxidase B inhibitors for the treatment of Parkinson's and Alzheimer's diseases. Neurosci Lett. 2005;382:327-331.

21. Jayaprakash V, Yabanoglu S, Sinha N, Ucar G. Pyrazoline-based mycobactin analogues as dual inhibitors of mao/cholinesterase. Turk $\mathrm{J}$ Biochem. 2010;35:91-98.

22. Mishra N, Sasmal D. Additional acetyl cholinesterase inhibitory property of diaryl pyrazoline derivatives. Bioorg Med Chem Lett. 2013;23:702-705.

23. Shah MS, Khan SU, Ejaz SA, Afridi S, Rizvi SUF, Najam-ul-Haq M, Iqbal J. Cholinesterases inhibition and molecular modeling studies of piperidylthienyl and 2-pyrazoline derivatives of chalcones. Biochem Biophys Res Commun. 2017; 482:615-624.

24. Turan-Zitouni G, Ozdemir A, Kaplancikli ZA, Altintop MD, Temel HE, Çiftçi GA. Synthesis and biological evaluation of some thiazole derivatives as new cholinesterase inhibitors. J Enzyme Inhib Med Chem. 2013;28:509514.

25. Altintop MD, Özdemir A, Kaplancikli ZA, Turan-Zitouni G, Temel HE, Çiftçi GA. Synthesis and biological evaluation of some pyrazoline derivatives bearing a dithiocarbamate moiety as new cholinesterase inhibitors. Arch Pharm (Weinheim). 2013;346:189-199. 
26. Havrylyuk D, Roman O, Lesyk R. Synthetic approaches, structure activity relationship and biological applications for pharmacologically attractive pyrazole/pyrazoline-thiazolidine-based hybrids. Eur J Med Chem. 2016;113:145-166.

27. Özdemir A, Altıntop MD, Kaplancıklı ZA, Zitouni GT, Çiftçi GA, Demirci F. Synthesis and biological evaluation of a new series of pyrazolines as new anticandidal agents. Pharm Chem J. 2014;48:605-614.

28. Özdemir A. Synthesis and antimicrobial activity of some pyrazoline derivatives bearing amide moiety. Marmara Pharm J. 2013;17:187-192.

29. Altıntop MD, Özdemir A, Turan-Zitouni G, Ilgın S, Atlı Ö, Demirel R, Kaplancıklı ZA. A novel series of thiazolyl-pyrazoline derivatives: Synthesis and evaluation of antifungal activity, cytotoxicity and genotoxicity. Eur J Med Chem. 2015;92:342-352.

30. Ellman GL, Courtney KD, Anders V Jr, Feather-Stone RM. A new and rapid colorimetric determination of acetylcholinesterase activity. Biochem Pharmacol. 1961;7:88-95.
31. Turan-Zitouni G, Altıntop MD, Özdemir A, Kaplancıklı ZA, Çiftçi GA, Temel HE. Synthesis and evaluation of bis-thiazole derivatives as new anticancer agents. Eur J Med Chem. 2016;107:288-294.

32. http://www.molinspiration.com. (Accessed August 2017).

33. Lipinski CA, Lombardo F, Dominy BW, Feeney PJ. Experimental and computational approaches to estimate solubility and permeability in drug discovery and development settings. Adv Drug Deliv Rev. 2001;46:3-26.

34. Veber DF, Johnson SR, Cheng HY, Smith BR, Ward KW, Kopple KD. Molecular properties that influence the oral bioavailability of drug candidates. J Med Chem. 2002;45:2615-2623.

35. Gabr MT, El-Gohary NS, El-Bendary ER, El-Kerdawy MM, Ni N. Synthesis, in vitro antitumor activity and molecular modeling studies of a new series of benzothiazole Schiff bases. Chinese Chem Lett. 2016;27:380386. 